\title{
Therapeutic Role of Piper nigrum L (Black Pepper) and Pharmacological Activities
}

\author{
Aisha Saleem ${ }^{1 *}$, Irum Naureen ${ }^{2}$, Muhammad Naeem $^{3}$, Gulnaz Tasleem ${ }^{1}$, Hassam Ahmed ${ }^{1}$, Umar Farooq ${ }^{1}$ \\ ${ }^{1}$ M. Phil Researcher, School of Zoology, Minhaj University Lahore, Pakistan \\ ${ }^{2}$ Assistant Professor, School of Zoology, Minhaj University Lahore, Pakistan \\ ${ }^{3}$ Institute of Research and Information Mirpur AJK, Pakistan
}

DOI: $\underline{10.36348 / \text { sijb.2022.v05i01.003 }}$

| Received: 15.12.2021 | Accepted: 22.01.2022 | Published: 27.01.2022

*Corresponding author: Aisha Saleem

M. Phil Researcher, School of Zoology, Minhaj University Lahore, Pakistan

\section{Abstract}

Black pepper, the King of spices (Piper nigrum L.), is a widely used spice, known for its pungent odour. From time immemorial, plant sources were used in traditional systems of medicine and day-to-day common use, such as in meal preparation and cosmetic purposes. This is due to their vast pharmacological potential with beneficial effects. Among the various species of the Piperaceae family, black pepper is one of the most popular due to its principle pharmacological component, piperine. Which is an alkaloid that has diverse pharmacological activities like antioxidant, antiobesity, antitumor, antipyretic, anticonvulsant, antithyroid, antifungal, antibacterial, insecticidal, hepatoprotective, antiasthmatic, larvicidal, antihypertensive, antiinflammatory, antidiabetic, antidiarrheal, bioavailability enhancer, immunomodulatory, antiepileptic, antifertility, GI stimulant, lipid metabolism accelerator, anticancer, CNS stimulant, diuretic, aphrodisiac, blood purifier and antiplatelet activities, etc. Due to the some religious values of black pepper, its being popular from ancient times which is beneficial to modern generation. This review is aimed to provide a literature review on recent advancement of chemistry, pharmacognosy, pharmacological activities, new Piperine based formulations and other general use of Piper nigrum.

Key words: Black Pepper, piper nigrum, Piperine, Antioxidant, Pharmacological applications.

Copyright (C) 2022 The Author(s): This is an open-access article distributed under the terms of the Creative Commons Attribution 4.0 International License (CC BY-NC 4.0) which permits unrestricted use, distribution, and reproduction in any medium for non-commercial use provided the original author and source are credited.

\section{INTRODUCTION}

Piper nigrum is belong to the family (Piperaceae) is a valuable medicinal plant. It is one of the most commonly used spices and considered as the King of spices among various spices. Black pepper is grown in many tropical regions like Brazil, Indonesia, Malaysia, Thailand, Madagascar, West Africa and India [1]. Piper nigrum is commonly known as Kali Mirch in Urdu and Hindi, Pippali in Sanskrit, Milagu in Tamil and Peppercorn, White pepper, Green pepper, Black pepper, Madagascar pepper in English. Hot and pungent pepper corns are obtained from Black pepper which is the most famous and one of the commonly used spices throughout the world. Black pepper is used as medicinal agent, a preservative, and in perfumery. Whole Peppercorn of Piper nigrum or its active components are being used in different types of foods and as medicine [2].

Black pepper is a tropical vine that can grow to a height of 4-9 m, but with the support of other treesThe leaves are simple, entire, elliptical, $10-15 \mathrm{~cm}$ long and $5-9 \mathrm{~cm}$ wide, thick, more or less leathery, and glabrous [3]. The fruit is a drupe up to $8 \mathrm{~mm}$ in diameter, better known as peppercorn [4]. The flowers are hermaphroditic, white, and usually 20 to 30 of them are grouped in pendulous spikes. The dried immature fruit of cultivated pepper plants is used as a drug. Black pepper fruit is ballshaped, $8 \mathrm{~mm}$ in diameter, brown with a mesh-wrinkled surface. It has a spicy taste, a specific smell [5]. Piper nigrum has many pharmacological activities like antihypertensive and anti-platelets, antioxidant, antitumor, anti-asthmatics, antipyretic, analgesic, anti-inflammatory, anti-diarrheal, antispasmodic, anxiolytic, antidepressant hepatoprotective, immuno-modulatory, antibacterial, antifungal, anti-thyroids, antiapoptotic, anti-metastatic, antimutagenic, antispermatogenic, insecticidal and larvicidal activities etc [6-8].

Piper nigrum has been used for medicinal purposes in many parts of the world since ancient times. 
Piperine has been found to enhance the therapeutic efficacy of many drugs, vaccines and nutrients by increasing oral bioavailability by inhibiting various metabolizing enzymes [8]. It is also known to enhance cognitive action and Fertility [9]. Piperine also found to stimulate the pancreatic and intestinal enzymes which aid to digestion. Many therapeutic activities of this spice are attributed to the presence of piperine apart from other chemical constituents. The fruits of Piper nigrum are used to produce white and green peppers. Piper nigrum is also used as a flavoring agent [10].

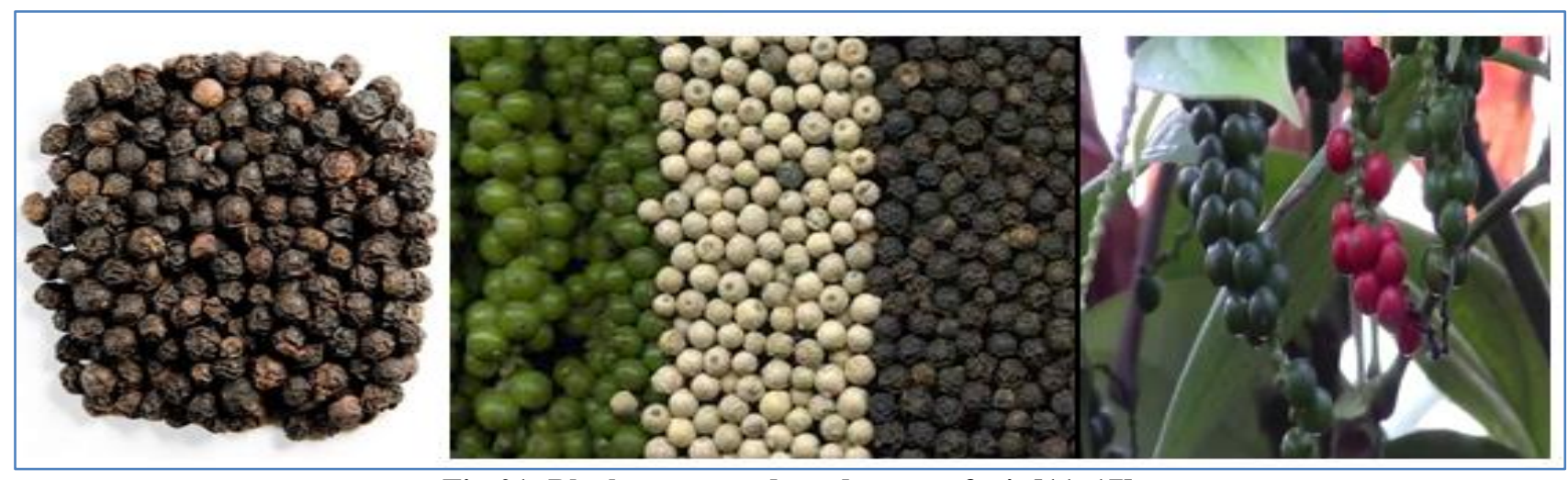

Fig-01: Black paper seeds and pepper fruit $[11,17]$

\section{Chemical composition}

Piper was the first pharmacologically active compound isolated from different members of Piperaceae family. Many investigators isolated different types of compounds viz Phenolics, flavonoids, alkaloids, amides and steroids, lignans, neolignans, terpenes, chalcones etc and many other compounds [15]. Proximate, minerals, vitamins and bioactive metabolites Black pepper is rich in minerals, vitamins and nutrient. Some of the compounds are Brachyamide B, Dihydro-pipericide, (2E,4E)-N-Eicosadienoylpereridine, N-trans-Feruloyltryamine, NFormylpiperidine, Guineensine, pentadienoyl as piperidine, (2E,4E)- Nisobuty- ldecadienamid, isobutyleicosadienamide, Tricholein, Trichostachine, isobutyleicosatrienamide, Isobutyl-octadienamide, Piperamide, Piperamine, Piperettine, Pipericide, Piperine, Piperolein B, Sarmentine, Sarmentosine, Retrofractamide [2]. These minerals are essential elements for day to-day activities of humans. Besides, black pepper also has a significant concentration of vitamins. The different pharmacological activities were reported due to the presence of these phytochemicals. Piperine reported to have four isomers Piperine, Isopiperine, Chavicine and Isochavicine. Among all isolated compounds isolated from Piper nigrum. Piperine, pipene, piperamide and piperamine were found to possess diverse pharmacological activities [16].

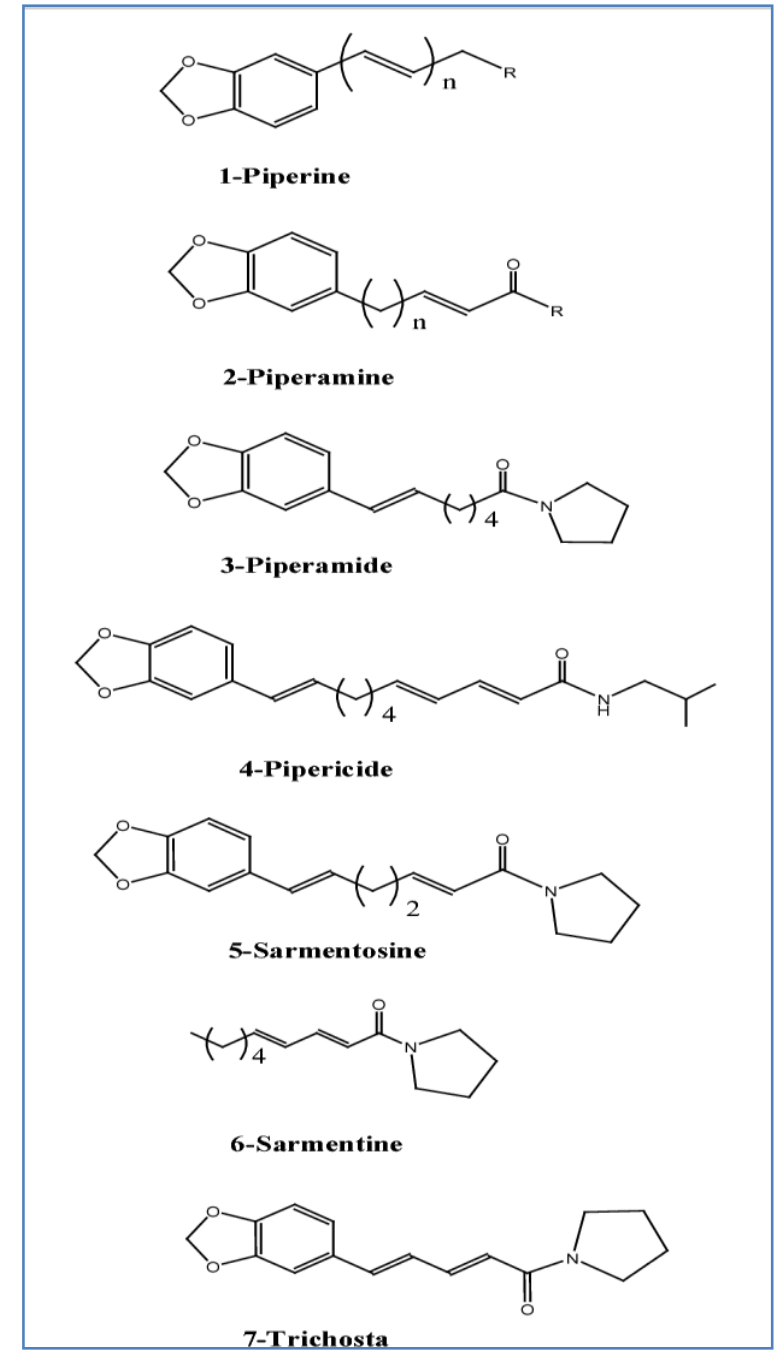

Fig-02: Some of the important chemical constituents of piper nigrum [16] 
Taxonomical Classification of Piper nigrum $[17,18]$

Nutritional composition of (piper nigrum $L$ ) $[19,20,21]$

\begin{tabular}{|c|c|}
\hline Water & $5.40-6.86(\mathrm{~g})$ \\
\hline Carbohydrate & $31(\mathrm{~g})$ \\
\hline Fat & $4.3(\mathrm{~g})$ \\
\hline Sodium & $61.6(\mathrm{mg})$ \\
\hline Protein & $9.3(\mathrm{~g})$ \\
\hline Calcium & $117.5(\mathrm{mg})$ \\
\hline Magnesium & $196.8(\mathrm{mg})$ \\
\hline Potassium & $111.6(\mathrm{mg})$ \\
\hline Phosphorus & $1.6(\mathrm{mg})$ \\
\hline Iron & $8.5(\mathrm{mg})$ \\
\hline Zinc & $1.4(\mathrm{mg})$ \\
\hline Vitamin $\mathrm{C}$ & $27.46-32.53(\mathrm{mg})$ \\
\hline Vitamin B1 & $0.74-0.91(\mathrm{mg})$ \\
\hline Vitamin B2 & $0.48-0.61(\mathrm{mg})$ \\
\hline Vitamin B3 & $0.63-0.78(\mathrm{mg})$ \\
\hline Tannin & $2.11-2.80(\mathrm{mg})$ \\
\hline Flavonoids Catechin & $410.0(\mu \mathrm{g})$ \\
\hline Myricetin & $56.0(\mu \mathrm{g})$ \\
\hline Quercetin & $13.0(\mu \mathrm{g})$ \\
\hline Carotenoids Lutein & $260.0(\mu \mathrm{g})$ \\
\hline$\beta$-carotene & $150.0(\mu \mathrm{g})$ \\
\hline \multicolumn{2}{|c|}{ Kingdom : Plantae } \\
\hline \multicolumn{2}{|c|}{ Class: Equisetopsida } \\
\hline \multicolumn{2}{|c|}{ Sub class: Magnoliidae } \\
\hline \multicolumn{2}{|c|}{ Super order: Magnolianae } \\
\hline \multicolumn{2}{|c|}{ Order: Piperales } \\
\hline \multicolumn{2}{|c|}{ Family: Piperaceae } \\
\hline \multicolumn{2}{|c|}{ Genus: Piper } \\
\hline & Species : piper nigrum \\
\hline
\end{tabular}

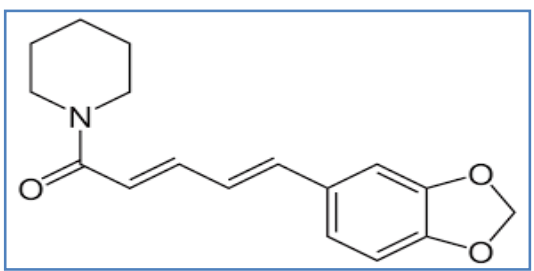

Fig-03: Piper nigrum (black paper) Piperine [45]

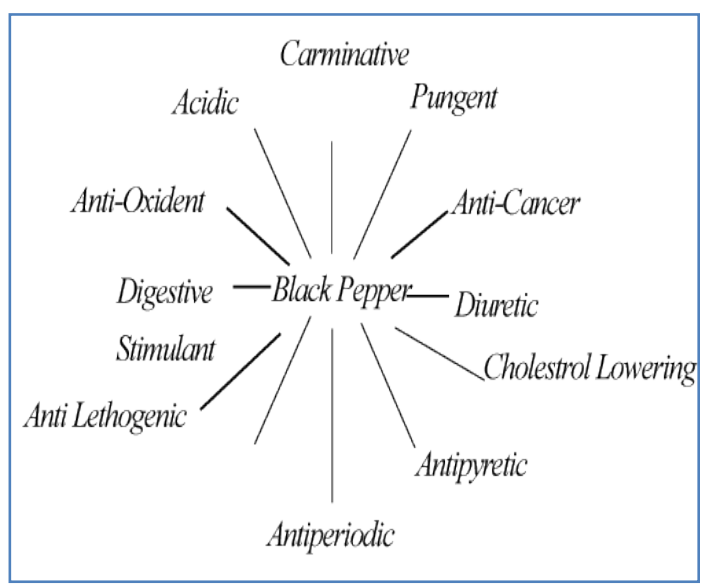

Fig-04: Black pepper (Piper nigrum L) uses and physiological effects [22] 


\section{Pharmacological activities of piper nigrum}

\section{Antimicrobial activity of Black pepper}

An antimicrobial is an agent that kills microorganism or inhibits their further growth. These antimicrobial agents can be grouped into different categories according to their primary activity, like antibacterial, antifungal, antiviral, anti-parasitic, pesticide, etc [25]. Black pepper showed strongest antibacterial activity remains unclear till date.In a recent study, the silver nanoparticles from leaf and stem extract of Piper nigrum were synthesized and then antibacterial activity of the synthesized silver nanoparticles of Piper nigrum was evaluated against agricultural plant pathogens [25]. These silver nanoparticles showed the excellent antibacterial activity against plant pathogens. Authors concluded that the antibacterial activity of silver nano-particles is a beneficial application in crop improvement and protection in agricultural nanotechnology [26].

\section{Anti-obesity Activity}

Obesity is becoming a global problem, since it is a socially stigmatized health problem. Piper nigrum is used as an herbal medicine and other nonpharmacological way of management of obesity like exercise, yoga, meditation, diet control etc. There are so many plants that have anti-obesity potency among them [27].

\section{Carminative Activity}

Pepper has a high degree of the stimulating and carminative properties, causing a reflex flow of saliva, with increased secretion of gastric juice and improved appetite. Gastro-intestinal movements are augmented, with consequent eructation of gas and relief of colic. In sufficient doses, the peppers dilate the superficial vessels of the skin, causing a feeling of warmth, followed by diaphoresis and some reduction of temperature [25]. On account of these properties they are much employed as condiments, especially in hot countries. The pathological condition in which such painful masses occur, also called piles and black pepper is used as remedy for hemorrhoids. An oleoresin of pepper is prepared by extraction with acetone and separation from Piperine [7].

\section{Cholesterol Lowering and Immune Enhancer Activity}

Black pepper and Piperine reduce cholesterol uptake and enhance translocation of cholesterol transporter proteins [29]. It enhances digestion process by helping faster break down of larger fat molecules into easily digestible simple molecules and prevents the accumulation of fat in body. Black pepper exhibits immunomodulatory effect on human body [30]. Piper nigrum is one is used supplementing piperine with high fat diet $(40 \mathrm{mg} / \mathrm{kg})$ significantly reduced not only body weight, total cholesterol, triglyceride, LDL, VLDL and fat mass but also increased the level of HDL, with no change. The dietary intake of black pepper or piperine reduces the risk of arthrosclerosis via hypolipidemic and antiatherogenic effects [31].

\section{Anti-mutagenic, Antitumor and Anticancer Activity}

Cancer is becoming global challenge in today's health system. Although enormous efforts are done and going on to find new technology, drugs, research, surgery, it is still insufficient. So, we need to search such systems where negligible side effect with high therapeutic outcomes. (Piper Nigrum L) showed effective immunomodulatory and antitumor activity. Angiogenesis plays a key role in tumor progression and cancer. Research findings show that Piperine inhibits proliferation and $\mathrm{G} 1 / \mathrm{S}$ transition of human umbilical vein endothelial cells [32].

\section{Antioxidant activity}

Black pepper contains an important source of natural antioxidant. The main role of antoxidant protects cells against free radicals, which may play a role in heart disease, cancer and other diseases. Free radicals are molecules produced when your body breaks down food or when you're exposed to tobacco smoke or radiation [33]. The importance of antioxidants for maintaining the physiological functions of liver, kidney, digestive system, and prevention of cardiovascular diseases and cancer. They have beneficial influence on lipid metabolism efficacy as antidiabetic [34].

\section{Digestive activity of black pepper}

Dietary piper nigrum enhances digestion by stimulation of the pancreatic enzymes and considerably decreases the food transit time of gastrointestinal tract. To increases the saliva production and gastric secretions, and increases the production and activation of salivary amylase [35]. The orally administration of Piperine or Piper nigrum stimulate the liver to the secrete bile acids which in turn play key role in the absorption and digestion of fats [36].

\section{Anti-pyretic activity}

Ayurvedic, Yunani, Siddha and folklore medicines in India used pepper and pepper containing preparations for the treatment of intermittent fever, neuritis, cold, pains and diseases of throat are practiced in Pepper is also used as an anti-periodic in malarial fever and therefore it is claimed having analgesic and antipyretic properties [36]. Analgesic and antipyretic actions of piperine have been experimented and found strong antipyretic effect [37].

\section{Antidiarrhoeal Effect}

Along with above described antimicrobial activity of black pepper, against some bacteria which are also responsible for causing diarrhea. Other research signifies its great potency in controlling diarrhea [38]. As we know, diarrhea is a leading cause of morbidity and mortality globally, especially among the children in developing countries. Aqueous extract of black pepper 
at a dose of $75,150,300 \mathrm{mg} / \mathrm{kg}$, produces a significant dose dependent antimotility, anti-secretary and Antidiarrhoeal effects. This effect is due to the presence of alkaloids in black pepper [39].

\section{Immunomodulatory activity of black pepper}

Immunomodulatory and antitumor activity of piper nigrum was evaluated. Black pepper and cardamom exert immunomodulatory roles and antitumor activities, and hence they manifest themselves as natural agents that can promote the maintenance of a healthy immune system. Immunomodulation of Piperine for the use of cytokine production, macrophage activation and lymphocyte proliferation [40, 41].

\section{Other pharmacological activities}

Piper nigrum (Black Pepper) or pure compound "Piperine" exhibits many more Pharmacological activities like antihypertensive, antiplatelets, antipyretic, antispasmodic, antifungal, anti-apoptotic, anti-metastatic, antimutagenic, antispermatogenic, anti-Colon toxin, anti-asthmatics, antianxiety, antithyroids, antifungal, insecticidal and larvicidal activities etc [42-44].

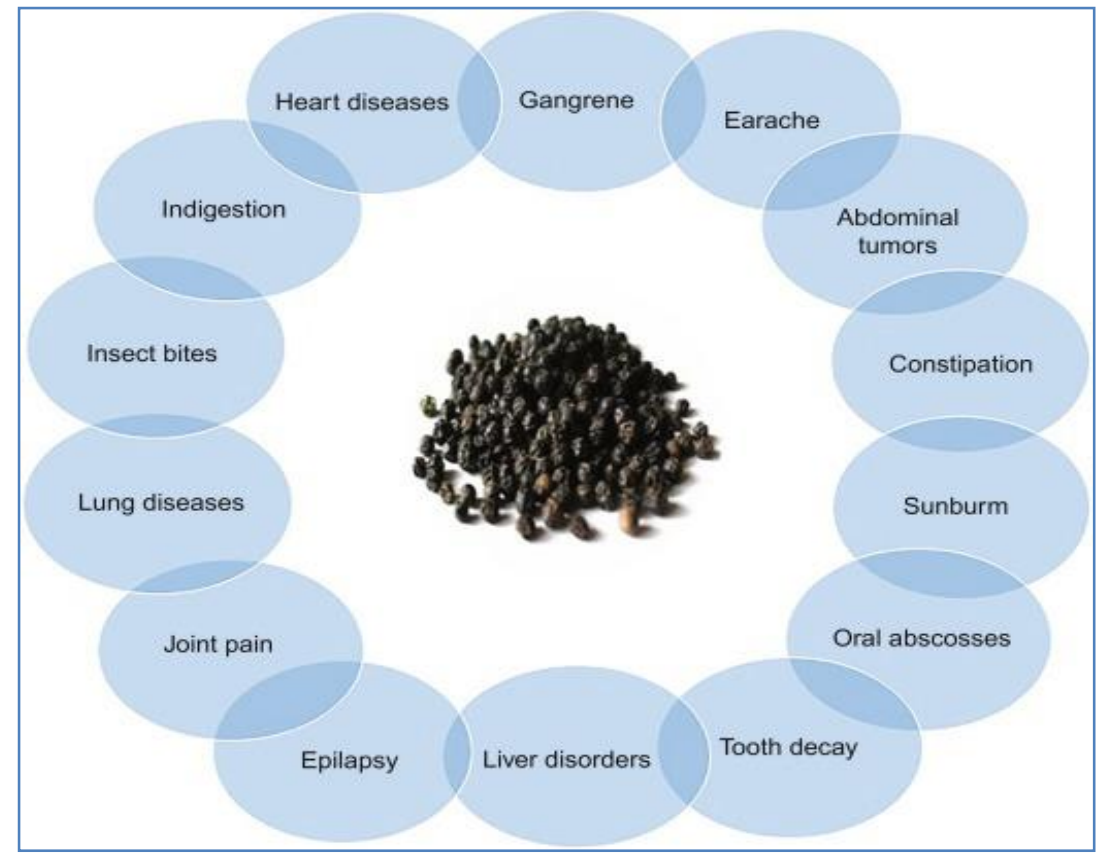

Fig-05: Benificial uses of piper nigrum ( Black paper) [46]

\section{CONCLUSION}

Pepper has been used since ancient times as a spice, but it has also been used in various traditional medical preparations, Black pepper is a very rich source of a wide variety of chemical constituents, most of which are biologically active. Piper nigrum longum revealed that it has got a variety of pharmacologically and medicinally significant constituents, which are being utilized in the field of Ayurveda. It is a plant of high commercial and economical importance. The black pepper fruits (Piper nigrumL.) are the king of spices and used all over the world. This spice has many health benefits and used traditionally to treat different ailments. The chemical composition of black pepper, which is including minerals, vitamins, Carotenoids and flavonoids, and various therapeutic and biological, and pharmacological activities. Piperine also has a broad spectrum of therapeutic potential and potential for improving health and beneficial use in liver joint pain, lung disease, and digestion, improves memory.

\section{REFERENCES}

1. Lim, T. K. (2012). Edible medicinal and nonmedicinal plants, Fruits, Springer Netherlands, Dordrecht, 4: 322- 351

2. Ahmad, N., Fazal, H., Abbasi, B.H., Farooq, S., Ali, M. (2012). Biological role of Piper nigrum L. (Black pepper): A review. Asian Pacific J Trop Biomed, S1945-S1953

3. Acharya S.G., Momin, A.H., \& Gajjar A.V. (2012). Review of Piperine as a BioEnhancer. American $J$ Pharm Tech Res, 2: 32-443. .

4. Yogesh M. S., Mokshapathy, S. (2013). Production and export performance of black pepper, International Journal of Humanities and Social Science Invention, 2(4): 36- 44.

5. Nelson, S. C.., K. T. Cannon-Eger. (2011). Black pepper, Farm and Forestry Production, 45(1); 114.

6. Gu, F., Huang, F., G. Wu., H. Zhu., H. (2018). Contribution of polyphenol oxidation, chlorophyll and Vitamin $\mathrm{C}$ degradation to the blackening of Piper nigrum L., Molecules, 23(2): 370-382 
7. Taqvi, S.I., Shah, A.J., Gilani, AH. (2008). Blood pressure lowering and vasomodulator effects of piperine. See comment in PubMed Commons below J Cardiovasc Pharmacol 52: 452-458.

8. Manoharan, S., Balakrishnan, S., Menon, V., Alias, L., Reena, A. (2009). Chemopreventive efficacy of curcumin and piperine during 7, 12dimethylbenz[a]anthracene-induced hamster buccal pouch carcinogenesis. Singapore Med J, 50:13946.

9. Parganiha, R., Verma, S., Chandrakar, S., Pal, S., Sawarkar, H.A., Kashyap, P. (2011). In vitro antiasthmatic activity of fruit extract of Piper nigrum (Piperaceae). Inter J Herbal Drug Res, 1; 15-18.

10. Li, S., Wang, C., Wang, M., Li, W., Matsumoto, K. (2007). Antidepressant like effects of piperine in chronic mild stress treated mlice and its possible mechanisms. See comment in PubMed Commons below Life Sci, 80: 1373-1381.

11. Matsuda, H., Ninomiya, K., Morikawa, T., Yasuda, D., Yamaguchi, I. (2008). Protective effects of amide constituents from the fruit of Piper chaba on D-galactosamine/TNFalpha-induced cell death in mouse hepatocytes. See comment in PubMed Commons below Bioorg Med Chem Lett, 18; 62038-62042.

12. Johnson, J.J., Nihal, M., Siddiqui, I.A., Scarlett, C.O., Bailey, H.H. (2011). Enhancing the bioavailability of resveratrol by combining it with piperine. See comment in PubMed Commons below MolNutr Food Res, 55; 1169-1176

13. Wattanathorn, J., Chonpathompikunlert, P., Muchimapura, S., Priprem, A., Tankamnerdthai, O. (2008). Piperine, the potential functional food for mood and cognitive disorders. See comment in PubMed Commons below Food Chem Toxicol, 46: 3106-3110.

14. Chaveerach, A., Mokkamul, P., Sudmoon, R. (2006). Ethnobotany of the genus Piper (Piperaceae) in Thailand. Ethnobotany Research \& Applications, 4; 223-231

15. Parmar, V.S., Jain, S.C., Bisht, K.S., Jain, R., Taneja, P., Jha, A. (1997). Phytochemistry of the genus Piper. Phytochemistry 46:597-673.

16. Z. Zarai., E. Boujelbene., N.B. Saleem, Y. Gargouri., A. Sayari. (2013). Antioxidant and antimicrobial activities of various solvent extracts, piperine and piperic acid from Piper nigrum. LwtFood Science and Technology, 50: 634-641

17. Pradeep, K.U., Geervani, P., Eggum, BO. (1993) Common indian spices: nutrient composition, consumption and contribution to dietary value. Plant Food Hum Nutr. 44:137-148

18. Al-Jasass, F.M., Al-Jasser, MS. (2012). Chemical composition and fatty acid content of some spices and herbs under Saudi Arabia conditions. Sci World J. https://doi.org/10.1100/2012/859892

19. Ashokkumar, K., Pandian, A., Murugan, M., Dhanya, M.K., Sathyan, T., Sivakumar, P., Surya, R., Warkentin, TD. (2020)Profiling bioactive flavonoids and carotenoids in select south Indian spices and nuts. Nat Prod Res, 34(9); 1306-10.

20. Nwofia, G.E., Kelechukwu, C., Nwofia, B.K. (2013). Nutritional composition of some Piper nigrum (L.) accessions from Nigeria. Int $\mathrm{J} \mathrm{Med}$ Arom Plants, 3; 247-54

21. Srinivasan, K. (2007). Black Pepper and its Pungent Principle-Piperine: A Review of Diverse Physiological Effects. Critical reviews in food science and nutrition, 47; 735-48. 10.1080/10408390601062054.

22. Sruthi, D., Zachariah, T.J., Leela, N.K., Jayarajan, K. (2013). Correlation between chemical profiles of black pepper (Piper nigrum L.) var. Panniyur-1 collected from different locations. J Med Plants Res; 7: 2349-57

23. L. Gorgani., M. Moham, G. D. Najafpour., M. Nikzad. (2017). Piperine the Bioactive Compound of Black Pepper: From Isolation to Medicinal Formulations. Comprehensive Review, 16(1); 124140.

24. Mošovská, S., Medvecká, V., Halászová, N., Ďurina, P., Valík, L., Mikulajová, A., \& Zahoranová, A. (2018) Cold atmospheric pressure ambient air plasma inhibition of pathogenic bacteria on the surface of black pepper. Food Research International. 106: 862-869. https://doi.org/10.1016/ j.foodres.2018.01.066.

25. Rani, S.K.S., Saxena, N., Udaysree. (2013). Antimicrobial activity of black pepper (Piper nigrum L.). Global J Pharmacol, 7; 87-90.

26. Morsy NFS, Abd El-Salam EA. (2017). Antimicrobial and antiproliferative activities of black pepper (Piper nigrum L.) essential oil and oleoresin. J Essential Oil Bearing Plants.;20:77990

27. Vijayakumar, R.S., Surya, D., Senthilkumar, R., and Nalini, N. (2002) Hypolipidemic effect of Black Pepper (Piper nigrum Linn.) in Rats Fed High Fat Diet. J. Clin. Biochem. Nutr. 32: 31-42.

28. L. Wang., V. Palme., S. Rotter, N. Schilcher, M. Cukaj, D. Wang, A. Ladurner., E. H. Heiss, H. Stangl., V. M. Dirsch., A. G. Atanasov. (2017). Piperine inhibits ABCA1 degradation and promotes cholesterol efflux from THP-1-derived macrophages. Mol Nutr Food Res. 61, 4: 1500960

29. Duangjai, A., Ingkaninan, K., Praputbut, S., \& Limpeanchob, N. (2013). Black pepper and piperine reduce cholesterol uptake and enhance translocation of cholesterol transporter proteins. Journal of natural medicines, 67(2), 303310.

30. Meghwal, M., Goswami, T.K. (2013). Piper nigrum and Piperine: An Update, Phytotherapy Research, 27(8); 1121-1130

31. Yang, Y., Kanev, D., Nedeva, R., Jozwik, A., Rollinger, J. M., Grzybek, W., \& Atanasov, A. G. (2019). Black pepper dietary supplementation increases high-density lipoprotein (HDL) levels in pigs. Current Research in Biotechnology, 1, 28-33. 
32. Damanhouri, Z. A., \& Ahmad, A. (2014). A review on therapeutic potential of Piper nigrum L. Black Pepper): The King of Spices. Med. Aromat. Plants, 3, 161.

33. Hlavačková, L., Janegová, A., Uličná, O., Janega, P., Černá, A., \& Babál, P. (2011). Spice up the hypertension diet-curcumin and piperine prevent remodeling of aorta in experimental L-NAME induced hypertension. Nutrition \& metabolism, 8(1), 1-10.

34. Murlidhar, Meghwa. 1., \& Goswami, T.K. (2012). Chemical Composition, Nutritional, Medicinal and Functional Properties of Black Pepper: A Review, Scientific Reports, 1(2): $172-173$ http://dx.doi.org/10.4172/scientificreports. 172

35. Hussain, A., Naz, S., Nazir, H., Shinwari, Z.K. (2011). Tissue culture of Black pepper (Piper nigrum L.) in Pakistan. Pak J Bot, 43; 1069-1078.

36. Srinivasan, K. (2007). Black pepper and its pungent principle-Piperine: a review of diverse physiological effects. See comment in Pub Med Commons below Crit Rev Food Sci Nutr , 47; 735748.

37. Damanhouri, Z.A., Ahmad, A. (2014). A Review on Therapeutic Potential of Piper nigrum L. (Black Pepper): The King of Spices. Med Aromat Plants 3: 161. doi: 10.4172/2167-0412.1000161

38. Pany, S., Abhisek, P., Pratap, K.S. (2016). Potential neuroprotective effect of Piperine in pilocarpine induced temporal lobe epilepsy. Am J Pharm Res, 6:4369-4375

39. Shamkuwar, P.B., Shahi, S.R., \& Jadhav, S.T. (2012). Evaluation of anti-diarrheal effect of Black pepper (P. nigrum L). Asian Journal of Plant Science and Research, 2; 48-53.

40. Acharya, S.G., Momin, A.H., \& Gajjar, A.V. (2012). Review of Piperine as a BioEnhancer. Am J Pharm Tech Res, 2; 32-44 3.

41. Taqvi, S.I., Shah, A.J., Gilani, A. H. (2008). Blood pressure lowering and vasomodulator effects of piperine. See comment in PubMed Commons below J Cardio vasc Pharmacol, 52; 452-458.

42. Manoharan, S., Balakrishnan, S., Menon, V., Alias, L., Reena, A. (2009). Chemopreventive efficacy of curcumin and piperine during 7, 12dimethylbenz[a] anthracene-induced hamster buccal pouch carcinogenesis. Singapore Med J 50:139-46.

43. Parganiha, R., Verma, S., Chandrakar, S., Pal, S., Sawarkar, H.A., Kashyap, P. (2011). In vitro antiasthmatic activity of fruit extract of Piper. Inter $J$ Herbal Drug Res, 1:15-18.

44. Kunnumakkara, A. B., Bordoloi, D., Padmavathi, G., Monisha, J., Roy, N. K., Prasad, S., Aggarwal, B. B. (2017). British Journal of Pharmacology, 174(11): 1325-1348. 